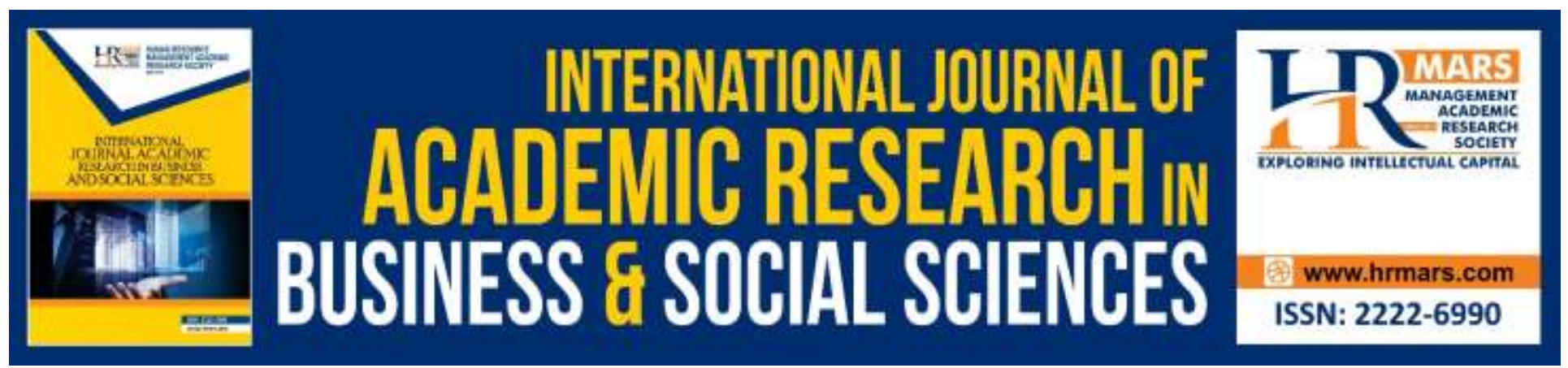

\title{
Importance of Performance Measurement and Intellectual Capabilities in Government Sector of Malaysia.
}

Intan Safura Abdul Rahman, Shahimi Mohtar

To Link this Article: http://dx.doi.org/10.6007/IJARBSS/v10-i5/7321

DOI:10.6007/IJARBSS/v10-i5/7321

Received: 18 March 2020, Revised: 21 April 2020, Accepted: 09 May 2020

Published Online: 29 May 2020

In-Text Citation: (Rahman \& Mohtar, 2020)

To Cite this Article: Rahman, I. S. A., \& Mohtar, S. (2020). Importance of Performance Measurement and Intellectual Capabilities in Government Sector of Malaysia. International Journal of Academic Research in Business and Social Sciences, 10(5), 900-908.

Copyright: (c) 2020 The Author(s)

Published by Human Resource Management Academic Research Society (www.hrmars.com)

This article is published under the Creative Commons Attribution (CC BY 4.0) license. Anyone may reproduce, distribute, translate and create derivative works of this article (for both commercial and non-commercial purposes), subject to full attribution to the original publication and authors. The full terms of this license may be seen at: http://creativecommons.org/licences/by/4.0/legalcode

Vol. 10 , No. 5, 2020, Pg. $900-908$

Full Terms \& Conditions of access and use can be found at http://hrmars.com/index.php/pages/detail/publication-ethics 


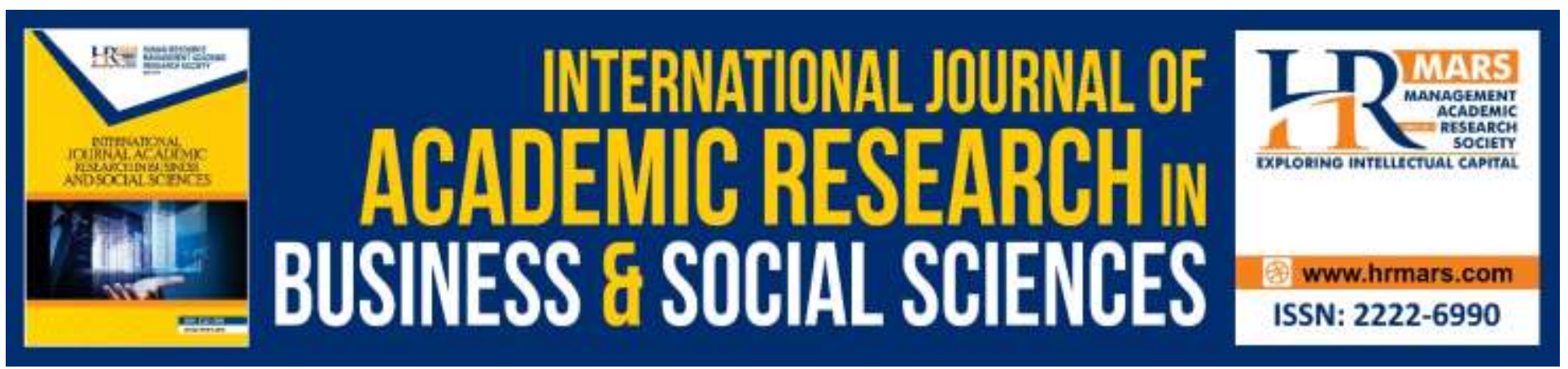

\section{Importance of Performance Measurement and Intellectual Capabilities in Government Sector of Malaysia.}

\section{Intan Safura Abdul Rahman, Shahimi Mohtar}

School of Technology Management and Logistic, College of Business, Universiti Utara Malaysia, Kedah, Malaysia.

\section{Abstract}

The aim of the study is to analyze relationship between Performance and Intellectual Capital on Government Sector Organization in Malaysia. The Government sectors have introduced several managerial techniques within their organizations in order to serve better services. These managerial techniques involve measuring an individual's performance and intellectual capabilities and rewarding them accordingly. With the implementation of new rewarding system, the morale of the employees remains high thus resulting in higher profit turnovers. These management techniques were borrowed from the private sector organizations, which are making a lot more profit than the public sectors. The change in economy of Malaysia due to the implementation of newer management rules has been described in the below subsection.

Keywords: Government Sector, Performance, Intellectual Capital.

\section{Introduction}

Intellectual capital and innovative capabilities are the keys to success in the highly competitive surroundings of any workplace. The Government sectors provide some of the best-paid jobs and thus require its employees to possess a high level of intellectual and innovative capabilities. Now days, Malaysia one of the leading open economies of the world has adopted the process of measuring the performance and innovation capability of its employees. Intellectual capital can be defined as a tangent value for business and combines human, relation and structural capital of the business. Other while, intellectual capital can create value and consequently determines the performance of an organization whilst innovation capability refer to the ability of an organization to transform an idea into something new which carries an economic value. In short, it comprises of everything within an employee's knowledge that might help to keep the company a few steps ahead of its competitors. Advancement of a company largely depends on its innovative capabilities. Determining the innovative capabilities of an organization forms a crucial prerequisite for more efficient and innovative management. Measurement of achievement is a common practice among all organizations, which help them determine the exact worth of the organization. The main objectives 
INTERNATIONAL JOURNAL OF ACADEMIC RESEARCH IN BUSINESS AND SOCIAL SCIENCES

Vol. 10, No. 5, May, 2020, E-ISSN: 2222-6990 @ 2020 HRMARS

for the measurement of employee performance are accountability and improvement. It involves systematically collect, analyse, and report information to management.

\section{Significance of Performance Measurement}

With the paradigm shift towards the entrepreneurial government, individual performance is considered an important factor while doing business in the government sectors also. The public sector, although a bit different from the private sectors now is treated like their business counterparts. Although many theories are present, practical applications of these theories is less prominent particularly in the public sector of Malaysia (Al Ahbabi et al. 2019). The governments are under a constant pressure to be responsive and accountable to not just the departmental head, ministers and the parliament, but also to all of its clients involved. An increasing number of governments are trying to improve their efficiency by creating ways to measure and evaluate individual performances. In the last two decades, several companies have introduced performance measurement systems, which are based on the critical success rate, and the key performance indicators of the company involved. Private organisations have implemented much-advanced tools for performance measurement such as Activity-based Costing Management, Benchmarking, Total Quality Management, and the best being the Balanced Scorecard. The CVM or Competing Value Model developed by Quinn and Rohrbaugh was introduced with the intention of investigating the various organizational phenomena. The CVM uses two sets of competing values as its two axes, one being control flexibility dilemma and the second being people organization dilemma (Ali, Mahat \& Mukhtar, 2017)

The Government of Malaysia is trying to implement performance-based monitoring and evaluation of government projects and programs to fight against the issues preventing a sustainable government. Financial indicators such as cost, sales, and return are at the heart of the accounting performance measurement. Performance measuring systems are required for tracking the execution of a strategy, to compare and analyse the strategies and to contrast the outcomes.

Performance measurement can be defined several ways; the most common of them defines it as a process of collection, analysis, and reporting of information systematically to the management. It can also be defined as the process of measuring past actions. Performance measurement is calculated based on questions from three sections, which are Strategy, Respondent Background, and Performance Measurement. The strategy section may allow the respondent to share their personal understanding of a strategy as well as its relationship regarding performance measurement while the performance measurement section focuses on design, implementation, and usefulness of Performance Measurement Systems in their respective workspace. Study of data received from the survey are exploratory in nature and are thus analyzed using descriptive statistics which gives the general idea of the current state of the performance measurement systems in Malaysia (Bakar, Rasid \& Rizal, 2016).

The utilization of financial and non-financial measurement can be considered as the simplest way to develop a system for Performance Measurement. With the recognition of exceptional performance, an employee is rewarded which gives rise to higher morale among the employees. With the temptation of incentives, the employees receive a morale boost while trying to achieve their goal. This recognition of performance helps the employee to be more confident thus allowing them to take on more responsibilities. Two recent studies have found that performance measurement systems comprising of both financial and non-financial assets are directly related to managerial performances 
INTERNATIONAL JOURNAL OF ACADEMIC RESEARCH IN BUSINESS AND SOCIAL SCIENCES Vol. 10, No. 5, May, 2020, E-ISSN: 2222-6990 @ 2020 HRMARS

by means of role clarity. It is however, uncertain if these performances are totally related to either the financial or the non-financial assets alone. Based on a study on 121 managers it has been determined that the non-financial assets alone have a significant influence on managerial performance depending on role clarity. It has also been seen that the non-financial assets affect the role clarity much greater than the financial assets (Kearney, 2018).

The main reason for this study is to investigate the function of stock-based incentives for encouraging more voluntary disclosures on company-specific intangibles. With the annual report of some high tech firms, it is found that stock-based incentives are directly related to voluntary disclosures. This proves that strong governance will strengthen the positive feedback on the stockbased incentives suggesting governance and incentives are complements. A graphical representation of the agricultural sector of Malaysia over a period of 5 years has been described below (Manikam, Sahibudin \& Selamat, 2017).

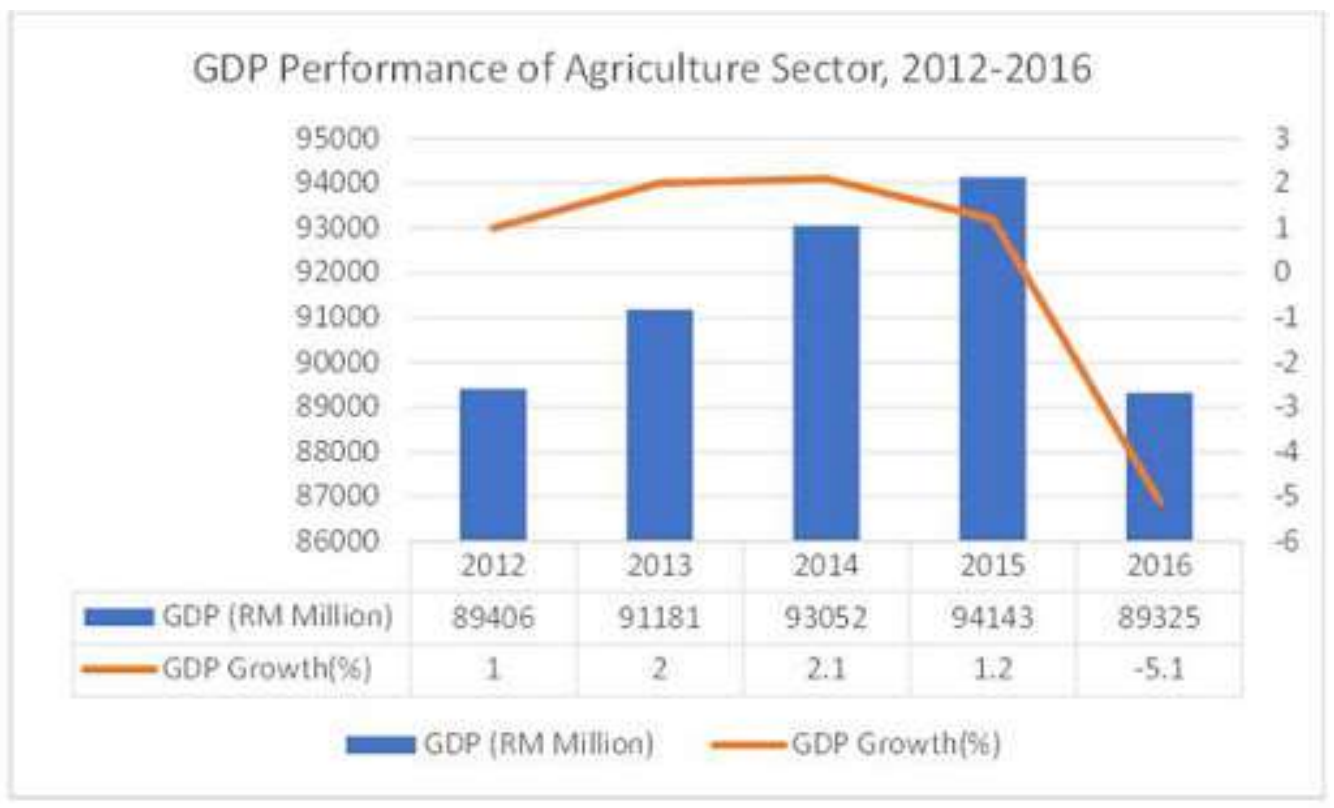

Figure 1: GDP performance of the Agriculture Sector of Malaysia

(Source: Manikam, Sahibudin \& Selamat, 2017)

The above image represents the flow of GDP of the Agricultural Sector of Malaysia since 2012. As is evident from the image, it is seen that Malaysia was going through a constant state of increase since 2012. This was the year when Performance Measurement and Innovation Capability of every individual came under direct observation and the new methods of management were introduced in the public sectors. Employees were given incentives based on their achievements and thus their productivity increased over time. It can be seen there is a constant growth in the GDP until 2014, however, after the global recession since 2014, the Malaysian government is also affected. Ever since then the GDP on their agriculture, sectors have fallen to a record-breaking low. From a maximum growth recorded at 2.1 in 2014, the GDP growth has fallen by -5.1 in 2016 (Ramadass, Sambasivan \& Xavier, 2017). 
INTERNATIONAL JOURNAL OF ACADEMIC RESEARCH IN BUSINESS AND SOCIAL SCIENCES Vol. 10, No. 5, May, 2020, E-ISSN: $2222-6990$ @ 2020 HRMARS

\section{Implication of Intellectual Capital}

According to Busbin, DeConinck \& Johnson-Busbin (2018), intellectual capital can be regarded considered as pivotal factor in today's knowledge-dependent economy and its element creation of an organization. Intellectual capital can be reflected as one of the key source for providing competitive advantages towards organizations. Intellectual capital leaves a major mark on the asset of the company and has significant success in the organization through understanding, developing, and company's non-significant assets. The intellectual capital achievements are as follows:

a) Human capital affects sales growth positively and it does not relate to the financial capitals.

b) Relationship capital has a negative relationship with sales and growth.

c) Human capital is not associated with reduced organizational costs but closely related to the increase in customer benefits.

d) Relationship capital does not show any significant relationship to increase benefits associated with less organizational costs.

e) Capital structure is related to reduce organizational costs and increases the interest of customers.

The relationship among intellectual capital and organization achievements of Malaysia has a vital significant relationship regarding that performance measurement regarding the firm's human capital market value in the knowledge-based industry (Manikam, Sahibudin \& Selamat, 2017). The value of intellectual capital is an investment decision factor that has at least comparable value with the value of traditional finance and physical assets and it is the determination for the organization growth, development, and evaluation based on analysis or investments. According to Draghici (2016), the intellectual capital provides a strong relationship with the government in order to provide effective and efficient methods to provide public goods and services and the reform public sector has the aim to make and ensure that procedure and government structure are effective to realize programs and development policies for the citizens.

Modern public sector enterprise management is interested with the attention on public and service quality and this justifies the need for intellectual capital as an approach to make the company more efficient and effective in the public sector (Manikam, Sahibudin \& Selamat, 2017). The intellectual capital mainly divided into few elements, which include human capital, structural capital, social capital, technological capital, customer capital, and finally spiritual capital.

\section{Human Capital}

The study has investigated and proved that an individual's intellectual capability is significant to the organizational performance. Human resource is considered as the most valuable and unavoidable asset within an organisation. Human capital can be denoted as knowledge, skills well as experience of an employee with the organization for generating values to the firm (Kianto, Sáenz \& Aramburu, 2017).

\section{Relational Capital}

Customer capital comprises of relationship with private organisations, the government or public sectors, brand names, trademarks, and reputation. The customer capital mainly analyses the organisation relationship and their level of satisfaction with the company (Rigolini et al. 2016). 
INTERNATIONAL JOURNAL OF ACADEMIC RESEARCH IN BUSINESS AND SOCIAL SCIENCES

Vol. 10, No. 5, May, 2020, E-ISSN: 2222-6990 @ 2020 HRMARS

\section{Structural Capital}

The structural capital mainly comprises of ideas, model, patents, computers and systems designed by employees who in turn are owned by the organization. In other words, an organization upgrades its technology, develops new processes, and is responsible for establishing another initiative. The structural capital would improve, and henceforth-structural capita denotes the ability of the organizations to allow the customer demands. The organization structure with skilled workers provides efficient as well as quality service with an even higher performance from the institution.

The main benefits of intellectual capital measurements are to meet invisible assets and its growth strategy in order to achieve the objectives of organizational benefits that include staff selfperception, innovation, and the motivation that creates a performance-oriented culture of the organization (Khalique et al. 2018). In order to evaluate the strategy achievement based on compensation for assisting in the formulation of the organization strategy. The importance of intellectual capability in the world and the government sector contribution towards the GDP of the country and it recognizes intellectual capability as an important resource through organisations needs improving competitive advantage to compete with other organization in the market. The intellectual capital in the public sector plays vital role because of the fact management in the public organization that is more tangible as compared to another private organization. The public administration tends to achieve goals of non-financial of productive resources and public administration entities uses the first ones that are intangible in public administration product and hence intellectual capital (Manikam, Sahibudin \& Selamat, 2017). This allows helping administrative officers and their objectives to achieve efficiency and effectiveness in public services in the public sector allows customers to evaluate their activities that the administration carries out in order to improve satisfaction of the citizens in the country in order to improve satisfaction of citizens to improve their wellbeing.

The intellectual capital management develops more quickly by public administration organizations than by the private sector due to following reasons such as by managing public administrations, information and knowledge and in many countries, public administration is currently processing reforms and integrating more models of effective management and more focused on the citizens. The relation between intellectual capability and performance measurement with the various organization, firms, products, innovative services in the various sector has the majority result which is positive and significant and its discuss the relation between intellectual capability and Malaysian public sector performance which leads to emerging the new challenges in the public sector (Shahveisi, Khairollahi \& Alipour, 2017).

\section{Relationship between performance and Intellectual Capital}

According to Khalique et al. (2018) the relation between performance and intellectual capital are affected by a number of different factors namely individual, organizations and social culture, scholars have researched that intellectual capital improves enterprise performance through its process. The intellectual capital can be denoted as the main competitive advantages in several business organisations. The intellectual capital is able to generate corporate wealth with the help of human capital and performance capital. By providing potential to create corporate wealth and analyse that the human capital and relational capital improves its performance making believe that human capital may change the consumer's view regarding an enterprise as well as relationship 
capital. This increases the brand image that enhances the performance of the enterprise and it is found that intellectual capabilities have positive effect on evaluation of the enterprise market. Enterprise profitable enhancements and intellectual capabilities are beneficial because of the values of enterprise and will have a positive relation regarding the business performance (Jordão, 2017).

The following study emphasises on exploring how the effect of intellectual capital is mediated by performance measurement systems. With the successful strives of private companies, the public sectors of Malaysia are also focussing their attention towards managerial systems used by private corporations. Performance measuring and individual innovative capability are being considered as some of the most important aspects in order to evaluate an employee. Rewards, promotions, and parting responsibilities are ways to encourage an employee and the aforementioned aspects evaluate an employee. Performance measurement includes the process of rewarding employees based on their overall performance and works efficiency. Intellectual capabilities of the employees working under the organisation are considered as an important resource as it may help the organisation to stay ahead of its competitors. Both of these aspects are considered the main basis for the promotion of an employee. The introduction of such a rewarding system in the organisation encourages the employees to work more efficiently, which in turn enriches the organisational performance. The Malaysian Government is trying to implement performance-based monitoring and evaluation of government projects to fight against issues preventing a sustainable government (Pirozzi \& Ferulano, 2016).

The performance measuring systems are beneficial for tracking, compare and analyse strategies and to contrast the outcomes. Performance measurement is based on Strategy, Performance Measurement, and Respondent Background (Asiaei \& Jusoh, 2017).

One of the most important aspects in today's knowledge-based economy is Intellectual capital. It is identified as a major asset an organisation possesses to stay ahead of its competitors. The implication of intellectual capital becomes more prominent by understanding, developing and utilizing the company's non-significant assets. The relationship between intellectual capital and organisational achievements are very significant for human resource. An individual's intellectual capabilities are also important aspect based on which an individual is promoted or rewarded in the organisation. It is evident that the individual's promotion is now totally based on their performance, which in turn encourages the employee to work harder. The appraisal and recognition of an individual's performance in the organisation boosts the morale making the workplace a better environment (Secundo et al. 2016).

\section{Conclusion}

The private sectors are utilising certain managerial techniques, which are resulting in the prosperity of their organisation and increase in their profits. The public sectors of Malaysia are also considering implication of such managerial techniques in order to increase their profit margin and thus maintain in its position as one of the leading global economies. The Government sectors are considering introducing performance measurement and intellectual capabilities as a way to evaluate their employees. Over the course of time, the Malaysian government found that there was a dynamic increase in the productivity of its employees resulting in an increase in profit turnover. By providing, the potential to create corporate wealth, the human capital, and relational capital improves the viewer's view of the organisation. The implications of performance and intellectual capabilities in the 
INTERNATIONAL JOURNAL OF ACADEMIC RESEARCH IN BUSINESS AND SOCIAL SCIENCES

Vol. 10, No. 5, May, 2020, E-ISSN: 2222-6990 @ 2020 HRMARS

private and public sectors of Malaysia all contribute towards the GDP of the country. The organisations need to improve their competitive advantage to compete with other organisations.

\section{Reference List}

Al Ahbabi, S. A., Singh, S. K., Balasubramanian, S., \& Gaur, S. S. (2019). Employee perception of impact of knowledge management processes on public sector performance. Journal of Knowledge Management.

Ali, N. A., Mahat, F., \& Mukhtar, R. (2017). Quality Governance and Performance Evaluation in Malaysian Public Sector. International Journal of Economics \& Management, 11.

Asiaei, K., \& Jusoh, R. (2017). Using a robust performance measurement system to illuminate intellectual capital. International Journal of Accounting Information Systems, 26, 1-19.

Bakar, B. A., Rasid, S. Z. A., \& Rizal, A. M. (2016). Risk Management Practices In The Malaysian Public Sector. Journal of Global Business \& Social Entrepreneurship, 1(2), 88-101.

Busbin, J. W., DeConinck, J., \& Johnson-Busbin, J. T. (2018). Strategic Implications of Intellectual Capital's Increased Contribution to Market Value. In Competition Forum (Vol. 16, No. 1, pp. 105-108). American Society for Competitiveness.

Gogan, L. M., Artene, A., Sarca, I., \& Draghici, A. (2016). The impact of intellectual capital on organizational performance. Procedia-social and behavioral sciences, 221(0), 194-202.

Jordão, R. V. D. (2017). Performance measurement, intellectual capital and financial sustainability. Journal of Intellectual Capital.

Kearney, R. (2018). Public sector performance: management, motivation, and measurement. Routledge.

Khalique, M., Bontis, N., Shaari, J. A. N. B., Yaacob, M. R., \& Ngah, R. (2018). Intellectual capital and organisational performance in Malaysian knowledge-intensive SMEs. International Journal of Learning and Intellectual Capital, 15(1), 20-36.

Kianto, A., Sáenz, J., \& Aramburu, N. (2017). Knowledge-based human resource management practices, intellectual capital and innovation. Journal of Business Research, 81, 11-20.

Manikam, S., Sahibudin, S., \& Selamat, H. (2017). Big Data Analytics Initiatives Using Business Intelligence Maturity Model Approach in Public Sector. Advanced Science Letters, 23(5), 40974100.

Martini, S. B., Corvino, A., Doni, F., \& Rigolini, A. (2016). Relational capital disclosure, corporate reporting and company performance. Journal of Intellectual Capital.

Pirozzi, M. G., \& Ferulano, G. P. (2016). Intellectual capital and performance measurement in healthcare organizations. Journal of Intellectual Capital.

Ramadass, S. D., Sambasivan, M., \& Xavier, J. A. (2017). Critical factors in public sector collaboration in Malaysia. International Journal of Public Sector Management.

Secundo, G., Dumay, J., Schiuma, G., \& Passiante, G. (2016). Managing intellectual capital through a collective intelligence approach. Journal of Intellectual Capital.

Shahveisi, F., Khairollahi, F., \& Alipour, M. (2017). Does ownership structure matter for corporate intellectual capital performance? An empirical test in the Iranian context. Eurasian Business Review, 7(1), 67-91.

Siti-Nabiha, A. K., Jeyaram, S., \& Jalaludin, D. (2020). Performance management of an externally imposed programme: a Malaysian case study. International Journal of Productivity and Performance Management. 
INTERNATIONAL JOURNAL OF ACADEMIC RESEARCH IN BUSINESS AND SOCIAL SCIENCES

Vol. 10, No. 5, May, 2020, E-ISSN: 2222-6990 @ 2020 HRMARS

Van Dooren, W., \& Van de Walle, S. (Eds.). (2016). Performance information in the public sector: How it is used. Springer.

Vitolla, F., Raimo, N., \& Rubino, M. (2019). Intellectual capital disclosure and firm performance: An empirical analysis through integrated reporting. In 7th International OFEL Conference on Governance, Management and Entrepreneurship: Embracing Diversity in Organisations. April 5th-6th, 2019, Dubrovnik, Croatia (pp. 245-255). Zagreb: Governance Research and Development Centre (CIRU). 